laboratory bench, a scheme of a power grid was designed. The structure of the power grid includes: the node of the power supply system (infinite power bus), taken as the basis; the load node, representing the active consumer with variable resistance; two nodes with connected synchronous generators, which in this case are reactive power control devices.

The results of this research showed the possibility of training ACS RPVC of a power grid with usage of ANN. Tests of the ACS RPVC allowed to prove the efficiency of the joint control devices regulating RPVC in the electrical power transmission.

\title{
CREATION OF A MEDICAL INFORMATION SEARCH SYSTEM IN THE ELECTRONIC MEDICAL CARD TO ASSIST IN DECISION-MAKING BY A DOCTOR
}

\author{
Khrushkov A.E. $^{{ }^{*}}{ }$, Ptuhin A.A. ${ }^{1}$ \\ 1) Ural Federal University, Yekaterinburg, Russia \\ *E-mail: deagle1@ mail.ru
}

Annotation. The purpose of this work is to create an assistant doctor, with which he can easily work with an electronic medical card, without spending too much time searching for the information he needs.

The doctor does not always see the whole picture, therefore, to decide or make the correct diagnosis, you need to visually look at the data that was collected during the examination of the patient. Be it a temperature chart, blood sugar or other tests.

There is a problem that could not be solved by introducing medical information systems. Such a problem is the analysis of the patient's card. With the introduction of an electronic medical record of the patient, the doctor must spend more time viewing the electronic medical record of the patient in search of the necessary tests and examinations than when using his paper equivalent. They tried to solve this problem by optimizing the interface, but this technique did not prove to be effective.

The healthcare system needs an informatization process. Informatization is a set of measures aimed at providing the participants of a given activity in a timely and complete manner with the necessary information, which has been processed in a certain way and, if necessary, transformed [1].

Informatization of the health care system is a multidimensional system-forming process, including the collection and accumulation of information, its transfer, integration, and the effective use of databases, databanks, and knowledge about the activities of the industry [2].

When writing an extension for Google Chrome, the main task was the choice of programming languages in which the front-end part of the application will be implemented. My choice fell on the following programming languages:

- JavaScript; 
- HTML5;

- CSS.

The development of this software product has allowed solving the problems of modern electronic medical records, by quickly accessing the necessary and useful information. This system is planned to be finalized in such a way that it itself would suggest options for the development of events, be it usual suggestions for conducting tests, and in the future, you can wipe out the correct diagnoses with the proposed treatment.

1. Gunter, Tracy D; Terry, Nicolas P. "The Emergence of National Electronic Health Record Architectures in the United States and Australia: Models, Costs, and Questions"( Journal of Medical Internet Research).

2. Informatization in healthcare (Electronic resource, URL: $\mathrm{http} / / / \mathrm{vmede}$. org/sait/?id=Obshesyvennoe_3d_shepin_2011\&menu=Obshesyvennoe_3d_shepin_2011\&page $=23$, accessed 03.06.2018).

3. Easy to Use Data Visualization Tools (Electronic resource, URL: https://datahero.com/features/how-it-works/, accessed 02.06.2018).

4. We make breakthrough products that change the way people use data (Electronic resource, URL: https://www.tableau.com/about, accessed 02.06.2018).

5. New file format options in the new Office (Electronic resource, URL: https://www.microsoft.com/en-us/microsoft-365/blog/2012/08/13/new-file-format-options-in-thenew-office/, accessed 02.06.2018).

\title{
РАЗВИТИЕ СИСТЕМЫ СИТУАЦИОННОГО УПРАВЛЕНИЯ КАЧЕСТВОМ ПОТОКОВ
}

\author{
Конев А.А.., Кудрявцев А.Г.
}

Уральский федеральный университет имени первого Президента России

Б.Н. Ельцина, г. Екатеринбург, Россия

*E-mail: int3rs3kt@gmail.com

\section{DEVELOPMENT OF THE FLOWS QUALITY SITUATIONAL MANAGEMENT SYSTEM \\ Konev A.A.*, Kudryavtsev A.G.}

Ural Federal University, Yekaterinburg, Russia

Annotation. The issue of development of the production technology quality situational management system, that gives it ability to work with natural language descriptions, is considered.

Известна система ситуационного управления качеством производственнотехнологических потоков [1], предполагающая описание ситуации в виде 